УДК 378.147. 016:81'243

DOI: $\underline{10.35619 / \text { iiu.v2i11.218 }}$

Дуброва Алла

аспірантка, викладач кафедри іноземних мов Рівненського державного гуманітарного університету,

м. Рівне, Україна

ORCID: 0000-0002-6576-4998

e-mail: alladubrova29@ukr.net

\title{
МЕТОДИЧНІ АСПЕКТИ ФОРМУВАННЯ ІНШОМОВНОГО ПРОФЕСІЙНО- ОРІЄНТОВАНОГО СПІЛКУВАННЯ МАЙБУТНІХ ФАХІВЦІВ
}

Анотація. У статті розглядаються деякі методичні аспекти формування іншомовного професійного спілкування майбутніх фахівців, виокремлюються методи, які оптимізують процес навчання. Аналізується важливість методичного забезпечення навчального процесу у закладах вищої освіти. Наголошується, що знання іноземної мови, вміння входити в іншомовне комунікативне середовище мають особливо важливе значення для конкурентоспроможного працівника. Зосереджується увага на тому, що професійна іншомовна підготовка майбутнього фахівця повинна грунтуватися на гнучкості навчальних програм та курсів підготовки, інтегрованості знань 3 професійно орієнтованих дисциплін та іноземної мови, а також на новітніх інформаційних технологіях.

Зазначається, що формування іншомовної комунікативної компетентності студентів немовних спеціальностей можна розглянути як підготовку до спілкування в умовах професійної діяльності. Уміння входити в іншомовне комунікативне середовище передбачає комплексне використання сукупності інноваційних методів і технологій навчання іноземної мови, а також організацію освітнього процесу, побудованого на основі компетентнісного і комунікативного підходів. Процес формування іншомовного профільно орієнтованого спілкування повинен бути спрямований не лише на оволодіння системою знань, вмінь та навичок, але й на формування комунікативної компетентності майбутнього фахівця, що своєю чергою сприятиме саморозвитку та самовдосконаленню в межах європейських стандартів.

Зміни, що відбуваються у соціальний сфері, зумовлюють трансформації в теорії і практиці іншомовної освіти. Нагальним є питання впровадження в освітній процес інтерактивних методів, інформаційно-комунікативних технологій. Вченими виділяється декілька методичних аспектів формування іншомовного професійно орієнтованого спілкування: навчальний аспект, пізнавальний аспект, виховний аспект, розвиваючий аспект.

У процесі утвердження стратегії міжкультурного спілкування, полікультурне професійне спілкування набуває все більшого значення серед провідних європейських країн. Володіння іноземною мовою передбачає як знання фонетики, лексики, граматики, так i іншомовної структури загалом. Це своєю чергою стає можливим у сукупності певних аспектів: навчальному, пізнавальному, розвиваючому та виховному.

Ключові слова: методичні аспекти, іншомовна професійна компетентність, методи, прийоми, іноземна мова. 
Постановка проблеми. В умовах глобалізації економіки, тісного переплетення інформаційних потоків саме іноземна мова стає універсальним засобом професійного розвитку. Розвиток сучасного українського суспільства та нові соціально-економічні умови у нашій державі призводять до розширення контактів фахівців різних країн. Володіння іноземною мовою, вміння вільно входити в іншомовне комунікативне середовище мають особливо важливе значення для конкурентоспроможного працівника, спроможного досягти вершин у професійній діяльності.

Професійна підготовка майбутніх фахівців «має орієнтуватись на перспективи міжнародної співпраці, забезпечення мобільності як науковців, викладачів, так і студентів у межах глобального освітнього і наукового простору. Приведення такої підготовки у відповідність до світових стандартів вищої освіти посилює значущість іiі іншомовного комунікативного компонента. Комунікація іноземними мовами розглядається членами Європейської комісії, Ради Європи та Європейського парламенту як одна з восьми ключових компетенцій, що формуються у процесі професійного навчання» (Микитенко 2011, с. 3).

Володіння іноземною мовою дозволить підвищити загальну компетентність майбутнього фахівця, допоможе краще адаптуватися в професійному світі, прискорюючи економічний розвиток всієї держави. Актуальною сьогодні є потреба у спеціалістах, які вільно володіють іноземними мовами, здатні підтримувати тісні ділові контакти із спеціалістами інших країн. Реформи у сфері вищої освіти України в умовах інтенсивного соціально-економічного розвитку мають на меті формування іншомовної комунікативної компетентності майбутнього фахівця, уміння застосовувати знання 3 іноземної мови у реалізації професійних завдань, спроможності здійснювати спілкування із закордонними фахівцями, а також виконувати професійну діяльність в умовах іншомовного середовища. Отже, змінюються потреби суспільства, а також й основні завдання методики іншомовної підготовки студентів у закладі вищої освіти - 3 читання та перекладу літератури за фахом на комплексне уміння здійснювати іншомовну комунікацію професійного спрямування.

Аналіз останніх досліджень 3 проблеми. 3 огляду на це проблема формування іншомовної комунікативної компетентності студентів немовних спеціальностей набула особливої актуальності й стала предметом низки наукових досліджень. Поняття іншомовної комунікативної компетентності у педагогіці й методиці навчання іноземних мов не нове i досліджувалось як зарубіжними, так і вітчизняними вченими. Окремі аспекти іншомовної підготовки майбутніх фахівців висвітлені в працях таких учених, як Р. Гуревич, І. Зязюн, В. Кремень (професійна підготовка фахівців). Проблеми, пов'язані з методикою викладання іноземних мов у вищій школі та формуванням іншомовної професійної компетентності, досліджували Д. Барська, І. Веретіна, П. Гальскова, Р. Гришкова, О. Єфімова, Г. Заволянська, Г. Китайгородська, 3. Коннова, Т. Кривошеєва, Р. Мартинова, Н. Микитенко, Н. Мойсеєнко, Л. Морська та ін.

Феномен комунікативної компетенції та компетентності вивчали А. Алексюк, М. Барна, Н. Бібік, В. Бондар, В. Буряк, І. Виноградова, Н. Власенко, Н. Гальскова,О. Кучеренко, О. Локшина, Т. Лучкіна, І. Мартьянова, О. Овчарук, О. Пометун, О. Решетова, О. Савченко, У. Уїдоусон, Л. Черній, В. Федорченко, Л. Халяпіна, С. Царьова та ін.

Визначенню іншомовної комунікативної компетентності як основної складової фахової підготовки спеціаліста присвячені наукові праці вчених Г. Абрамович, І. Вяхк, Н. Колотій, М. Паласюка, Н. Пруднікової, О. Тинкалюк та інших. Автори стверджують, що метою вивчення іноземної мови є не лише засвоєння ії фонетичного, лексичного та граматичного матеріалу, а й набуття професійно спрямованої іншомовної комунікативної компетентності задля ефективної самореалізації особистості у сфері фахової діяльності. 
Водночас здійснений аналіз наукових праць засвідчив, що проблема формування іншомовного професійно орієнтованого спілкування майбутніх фахівців розкрита недостатньо й потребує більш детального вивчення та аналізу.

Мета статті обумовлена теоретичною та практичною актуальністю проблеми і полягає у розкритті сутності іншомовної компетентності майбутніх фахівців, а також у висвітленні методичних аспектів у формуванні іншомовного професійно орієнтованого спілкування майбутніх фахівців.

Виклад основного матеріалу дослідження. Незаперечним фактом $є$ розуміння важливості володіння іноземною мовою на професійному рівні для фахівців різного профілю підготовки. Успіх іншомовного спілкування прямо пропорційно залежить від таких факторів, як наявність бажання підвищити рівень іншомовної комунікативної компетентності, що своєю чергою дозволить встановлювати контакти 3 носіями інших мовних культур; рівень володіння іноземною мовою та здатність користуватися нею у певних комунікативних ситуаціях. Усе це спонукає студентів до підвищення власного рівня іншомовної комунікативної компетентності.

У Загальноєвропейських рекомендаціях 3 мовної освіти визначено основні напрями професійної підготовки фахівців, що передбачають досягнення студентами немовного факультету достатнього рівня іншомовної комунікативної компетенції у професійній сфері спілкування (Ніколаєва, 2003, с. 273).

Метою навчання іноземної мови студентів немовних спеціальностей педагогічних ЗВО має стати практичне використання іноземної мови в майбутній професійно-педагогічній діяльності. Професійно орієнтоване навчання іноземної мови - це навчання, яке в межах навчального плану спрямоване на оволодіння студентами іноземною мовою відповідно до вимог певної професійної сфери (Образцов, 2005, с. 114).

Тобто, студенти повинні володіти іноземною мовою не лише як засобом загальнокультурного спілкування, але й як засобом спілкування в межах обраної спеціальності чи профілю навчання (читати та перекладати фахову літературу, володіти необхідною термінологією, правильно формулювати в усній та письмовій формі висловлювання іноземною мовою). При цьому профіль навчання у контексті дослідження розуміється нами як сформований тип підготовки 3 іноземної мови залежно від особливостей закладу вищої освіти та потреб студентів у володінні іноземною мовою як професійною. Саме профіль навчання визначає зміст, цілі та завдання навчання у певному закладі освіти, вимоги до рівня володіння іноземною мовою, який повинен бути досягнутий в результаті ефективної іншомовної підготовки. Однією з цілей профільного навчання іноземній мові є створення умов для розвитку навчально-пізнавальних і професійних інтересів студентів, формування готовності до оволодіння майбутньою професією. Заняття 3 іноземної мови у закладах вищої освіти нефілологічного профілю орієнтують студентів на оволодіння мовою як засобом спілкування в межах обраної ними спеціальності (Бідюк, 2010, c. 68).

Тому логічно, що засвоєння змісту професійно спрямованого курсу з іноземної мови здійснюється 3 урахуванням профілю закладу вищої освіти. Необхідно зауважити, що засобами дисципліни «Іноземна мова» формуються також навички професійної комунікативності майбутнього фахівця. При засвоєнні професійно орієнтованого змісту навчання студенти ознайомлюються із ситуаціями професійної діяльності, а це певною мірою створює умови для додаткової мотивації як до вивчення іноземної мови, так і до освоєння обраної спеціальності. 
Для успішного оволодіння майбутнім фахівцем знаннями з іноземної мови доводиться вирішувати багато проблем. Важливими завданнями є розробка дидактичних матеріалів для організації навчальної діяльності 3 дисципліни «Іноземна мова за професійним спрямуванням» у вищій школі, відбір адаптованого змісту та проєктування робочої програми, розробка навчально-методичного комплексу, постійне стимулювання та заохочення до самоосвіти і саморозвитку студента.

Методичне забезпечення мовної підготовки майбутніх фахівців поєднує в собі використання комплекту робочих програм, навчальних посібників, що містять теоретикоконцептуальні автентичні інформаційні джерела відповідної тематики з їх прикладною спрямованістю і робить їх професійно-орієнтованими. Сучасне методичне забезпечення освітнього процесу передбачає розроблення принципово нових навчальних проблем; розроблення і використання комп'ютерних навчальних програм; створення хрестоматій, енциклопедій тощо (Лащик, 1998, с. 52).

Вивчивши досвід викладання іноземної мови у ЗВО, доходимо висновку, що навчання студентів іноземної мови має на меті здебільшого накопичення знань збагачення словникового запасу, виконання граматичних вправ. Основою такого навчання $є$ заучування матеріалу напам'ять, а це, як відомо, не розвиває творчу активність студентів, не передбачає формування в них іншомовної компетентності. Мотивація до вивчення мови при цьому низька, тому що студенти не бачать можливості застосовати набуті знання у своїй майбутній професії.

Зосередимо увагу на впровадженні методу контент-навчання. Ця технологія полягає в одночасному викладанні іноземної мови та будь-якого іншого предмета зі спеціальності. Однією із моделей контент-навчання $є$ так звані допоміжні курси. Мовні курси запроваджуються у закладах вищої освіти будь-якого типу. У їхню основу закладено тематичний принцип, теми підбираються відповідно до інтересів студентів і вимог майбутньої професійної діяльності.

Необхідно зазначити, що ефективним під час занять $є$ використання ігрових методів навчання та ділові ігри, бо вони сприяють творчому розвиткові та самостійності студентів. Використовуючи такі методи, можемо зіткнутися із труднощами підбору самих ігор, недостатністю методичного матеріалу. Такий стан речей ми пояснюємо тим, що викладачі закладів вищої освіти не володіють достатньою інформацією про види, сутність і можливості інноваційних методів. Водночас сам факт їх використання свідчить про значний інтерес до цих методів, який можна успішно реалізувати завдяки відповідно розробленій методиці добору методів навчання. Проте для ефективного використання таких методів необхідно розробити відповідну систему методів, яку можна буде застосувати в ході викладання певної дисципліни, теми, враховуючи можливості студентів та вміння викладача їх застосовувати.

Підсумовуючи вищезазначене, зауважимо, що вдалий добір навчального матеріалу $є$ невід’ємною складовою освітнього процесу, адже саме актуальна й цікава тематика викладу матеріалу стане в нагоді в процесі підготовки майбутнього фахівця до професійної діяльності (Вовчаста, 2016, с. 44).

3 огляду на це, науковці наголошують, що сучасним досягненням у галузі методики навчання іноземних мов для спеціальних цілей $є$ такий висновок: «оскільки іноземна мова знаходить своє застосування в різних ситуаціях спілкування спеціалістів різних професій $\mathrm{i}$ різних спеціалізацій всередині професійної галузі, то, визначивши особливості типових ситуацій спілкування фахівців кожної конкретної галузі, можна моделювати процес їх реальної комунікації, i, відібравши попередньо необхідний для цього мовний та 
мовленнєвий матеріал, звузити весь широкий діапазон іноземної мови до конкретних потреб спеціалістів і цим полегшити процес оволодіння мовою для спеціальних цілей» (Теляшенко, 2003 , с. 80).

Висновки і перспективи подальших розвідок. Реалізація ідей перебудови сучасної освіти передбачає піднесення на якісно новий рівень наукове і методичне забезпечення освітнього процесу, зокрема включення комплексу засобів навчання, тобто джерел інформації, спрямованих на реалізацію методів і функцій навчання майбутніх спеціалістів. Формування іншомовної комунікативної компетентності студентів немовних спеціальностей можна розглядати як їхню підготовку до спілкування в різних умовах професійної діяльності. Такий підхід передбачає комплексне використання оновленого змісту та сукупності інноваційних методів і технологій навчання іноземної мови, а також організацію цілісного освітнього процесу, побудованого на основі компетентнісного i комунікативного підходів.

Подальші перспективи досліджень у цій сфері можуть включати питання вдосконалення змісту і формування іншомовного спілкування майбутніх фахівців у професійній сфері.

\section{СПИСОК ВИКОРИСТАНИХ ДЖЕРЕЛ}

Микитенко, Н. (2011). Теорія $і$ технологї формування іншомовної професійної компетентності майбутніх фахівців природничого профілю. Доктор педагогічних наук. Тернопіль. 43 с.

Ніколаєва, С. (2003). Загальноєвропейські рекомендації з мовної освіти: вивчення, викладання, оиінювання. Київ: Ленвіт. 273 с.

Образцов, П. (2005). Профессионально-ориентированное обучение иностранному языку на неязыковых факультетах вузов. Орел : ОГУ. 114 с.

Бідюк, Н. (2010). Теоретико-методологічні підходи у навчанні іноземної мови. Хмельницький: ХНУ. 194 с.

Лащик, I. (1998). Науково-методичне забезпечення навчального процесу при ступеневій підготовці спеціалістів. Реформування вищої освіти в Україні (закладів I-II рівнів акред.) : зб. матер. наук.-практ. конф. Київ. С. 52-55.

Вовчаста, Н. (2016). Науково-методичне забезпечення системи іншомовної професійної підготовки майбутніх фахівців цивільного захисту. Вісник Черкаського університету. Черкаси. Вип. 9. С. 41-46. (Серія «Педагогічні науки»).

Теляшенко, В. (2003). Професійно орієнтоване навчання студентів іноземної мови в немовному вузі. Теорія та практика державного управління: зб. Нац. акад. держ. упр. при Президентові України. Харк. регіон. ін-т. Вип. 4. «Актуальні питання навчання іншомовної комунікації у вищих навчальних закладах». Харків: Магістр. С. 78-81.

\section{REFERENCES}

Mykytenko, N. (2011). Teoriia $i$ tekhnolohii formuvannia inshomovnoi profesiinoi kompetentnosti maibutnikh fakhivtsiv pryrodnychoho profiliu [Theory and Technologies of Formation of Foreign Professional Competence for Future Specialists of Natural Profile]. Doctor Pedagogical Sciences. Ternopil. 43 s. (in Ukrainian)

Nikolaieva, S. (2003). Zahalnoievropeiski rekomendatsii z movnoi osvity: vyvchennia, vykladannia, otsiniuvannia [European Recommendations for Language Education: Study, Teaching, Assessment]. Kyiv: Lenvit. 273 s. (in Ukrainian) 
Obraztsov, P. (2005). Professionalno-orientirovannoe obuchenie inostrannomu iazyku na neiazykovykh fakultetakh vuzov. [Professionally-oriented Teaching of a Foreign Language at Nonlinguistic Faculties of Universities] . Orel: OGU. 114 s. (in Russian)

Bidiuk, N. (2010). Teoretyko-metodolohichni pidkhody u navchanni inozemnoi movy [Theoretical and Methodological Approaches in Teaching a Foreign Language]. Khmelnytskyi : KhNU. 194 s. (in Ukrainian)

Lashchyk, I. (1998). Naukovo-metodychne zabezpechennia navchalnoho protsesu pry stupenevii pidhotovtsi spetsialistiv. [Scientific and methodological Support of the Educational Process in the Stage Training of Specialists]. Reformuvannia vyshchoi osvity $v$ Ukraini (zakladiv I-II rivniv akred.) : zb. mater. nauk.-prakt. konf. Kyiv. S. 52-55. (in Ukrainian)

Vovchasta, N. (2016). Naukovo-metodychne zabezpechennia systemy inshomovnoi profesiinoi pidhotovky maibutnikh fakhivtsiv tsyvilnoho zakhystu. [Scientific and Methodological Support of the System of Foreign Language Professional Training of Future Civil Protection Specialists] Visnyk Cherkaskoho universytetu. Cherkasy. Vyp. 9. S. 41-46. (Seriia "Pedahohichni nauky"). (in Ukrainian)

Teliashenko, V. (2003). Profesiino oriientovane navchannia studentiv inozemnoi movy v nemovnomu vuzi. [Professionally Oriented Teaching of Foreign Language Students in a Nonlinguistic University]. Teoriia ta praktyka derzhavnoho upravlinnia: zb. Nats. akad. derzh. upr. pry Prezydentovi Ukrainy. Khark. rehion. in-t. Vyp. 4. "Aktualni pytannia navchannia inshomovnoi komunikatsii u vyshchykh navchalnykh zakladakh”. Kharkiv: Mahistr. S. 78-81. (in Ukrainian)

\title{
METHODICAL ASPECTS OF FORMATION OF FOREIGN LANGUAGE PROFESSIONALLY ORIENTED COMMUNICATION IN FUTURE SPECIALISTS
}

\author{
Alla Dubrova \\ Postgraduate Student, Lecturer at the Department of Foreign Languages, \\ Rivne State University for the Humanities, \\ Rivne, Ukraine \\ ORCID: 0000-0002-6576-4998 \\ e-mail: alladubrova29@ukr.net
}

\begin{abstract}
In the article some methodical aspects of formation of foreign-language professional communication of future specialists are considered, the methods which optimize the learning process are singled out. The importance of methodical support of educational process in higher educational institutions is analyzed. It is noted that knowledge of a foreign language, ability to enter a foreign-language communicative environment are especially important for a competitive employee.

It is noted that the formation of non-linguistic communicative competence of non-linguistic specialties students can be considered as training for communication in the conditions of professional activity.The ability to enter into a foreign-language communicative environment involves the integrated use of a set of innovative methods and technologies of learning a foreign language learning, as well as the organization of an educational process, built on the basis of competitive and communicative approaches. The process of forming a foreign-language profile oriented communication should be directed not only at mastering the system of knowledge, skills and skills, but also at the formation of communicative competence of a future specialist, which in turn will promote self-development and self-improvement within the European standards.
\end{abstract}


Changes occurring in the social sphere lead to transformations in the theory and practice of foreign language education. The urgent issue is the introduction of interactive methods, information and communication technologies in the educational process. There are several methodological aspects of the formation of professionally oriented foreign language communication by scholars: the educational aspect, the cognitive aspect, the educational aspect, the developing aspect.

In the process of establishing a strategy for intercultural communication, multicultural professional communication is becoming increasingly important among the leading European countries. Knowledge of phonetics, vocabulary, grammar, as well as foreign language structure in general, is required. This, in turn, becomes possible in a combination of certain aspects: educational, cognitive and developmental. Further research prospects in this area may include issues of improving the content and formation of foreign language communication of future specialists in the vocational field.

Key words: methodical aspects, foreign language professional competence, methods, techniques, foreign language.

Стаття надійшла до редакиії 26.02.2020 p. 